\title{
HUBUNGAN ANTARA POLA ASUH ORANGTUA DENGAN PERKEMBANGAN PERSONAL SOSIAL ANAK USIA PRASEKOLAH DI TK THOMAS AQUINO
}

\author{
RELATIONSHIP BETWEEN PARENTING AND \\ PERSONAL DEVELOPMENT OF PRESCHOOLERS \\ (4-6 YEARS) AT THOMAS AQUINO \\ KINDERGARTEN
}

\author{
Niken Ayu Merna Eka Sari' ${ }^{1}$, Marcelina Nita Alvina ${ }^{2}$, Ni Made Nopita Wati ${ }^{3}$. \\ STIKes Wira Medika Bali
}

\begin{abstract}
ABSTRAK
Pola asuh memiliki dampak yang signifikan bagi kesesuaian tahap perkembangan anak terlebih dari segi personal-sosial. Usia prasekolah dari segi personal, anak seharusnya mampu melakukan aktivitas sederhana secara mandiri, dari aspek sosial, ciri khasnya adalah mulai meluasnya lingkungan pergaulan anak. Dampak dari kegagalan atau keterlambatan perkembangan personal sosial adalah terjadinya frustasi pada anak karena anak tidak mampu bersosialisasi. Pemilihan pola asuh yang tepat dapat membantu anak mencapai tingkat perkembangan normal. Tujuan dari penelitian ini adalah untuk mengetahui hubungan antara pola asuh orangtua dengan perkembangan personal sosial anak usia prasekolah. Penelitian ini menggunakan desain penelitian korelasional dengan pendekatan cross sectional. Non probability sampling dengan teknik purposive sampling, jumlah sampel sebanyak 146 orang. Hasil penelitian 137 responden menerapkan pola asuh demokratis, 7 responden menerapkan pola asuh otoriter dan 2 kombinasi (demokratisotoriter). Hasil pengukuran perkembangan personal sosial, 69 anak termasuk kategori normal dan 77 anak termasuk kategori suspect. Uji yang digunakan adalah uji chi square dan uji Koefisien Kontingensi. Hasil uji korelasi chi-square didapatkan p value 0,014, dengan batas kemaknaan (alfa) sebesar $5 \%$, maka p value $<0,05$. Hasil ini menunjukkan bahwa terdapat perbedaan perkembangan personal sosial anak pada orangtua yang menerapkan pola asuh demokratis, otoriter atau kombinasi. Hasil uji koefisien kontingensi, atau contingency coefficientnya ( $\mathrm{r}$ ) adalah 0,236 , $\mathrm{p}$ value 0,014 dengan kesimpulan korelasi sangat lemah. Perawat diharapkan mampu melaksanakan tindakan promotif dan preventif guna menurunkan angka perkembangan personal sosial anak kategori suspect, serta mengoptimalisasi perkembangan personal sosial anak.
\end{abstract}

Kata kunci : Pola Asuh, Personal Sosial, Usia Prasekolah

ABSTRACT

Pparenting has a significant impact on the suitability of the child's stage of development in terms of personal-social. Preschool age in terms of personal, children should be able to perform simple activities independently, from the social aspect, the hallmark is the start of the social environment of children. The impact of the failure or 
delay of personal social development is the frustration of the child because the child is unable to socialize. Selection of appropriate parenting patterns can help the child achieve a normal level of development. The purpose of this study was to determine the relationship between parental parenting with the development of personal social preschoolers. This research uses correlational research design with cross sectional approach. Non probability sampling with purposive sampling technique, the number of samples counted 146 people. The results of the study of 137 respondents apply democratic parenting, 7 respondents implement authoritarian parenting and 2 combinations (democraticauthoritarian). Result of measurement of personal social development, 69 children including normal category and 77 children including category of suspect. The test used is chi square test and Contingency Coefficient test. Chi-square correlation test results obtained $p$ value 0.014, with a significance limit (alpha) of 5\%, then $p$ value $<0.05$. These results indicate that there are differences in personal social development of children in parents who apply democratic, authoritarian or combination parenting. The result of contingency coefficient test, or contingency coefficient is ( $r$ ) is 0,236, $p$ value 0,014 with very weak correlation conclusion. Nurses are expected to carry out promotive and preventive measures to reduce the rate of personal development of social categories of children suspect, as well as optimizing the child's personal social development.

Keywords: Pattern Foster, Personal Social, Preschool Age

\begin{tabular}{ll}
\hline $\begin{array}{l}\text { Alamat korespondensi } \\
\text { Email }\end{array}$ & $\begin{array}{l}\text { : Jalan Kecak No. 9A, Tonja, Denpasar Utara } \\
\text { : nikenmerna@yahoo.co.id }\end{array}$ \\
\hline
\end{tabular}

\section{PENDAHULUAN}

Pola asuh memiliki dampak yang signifikan bagi kesesuaian tahap perkembangan anak terlebih dari segi personal-sosial. Dewasa ini banyak dijumpai anak dengan tingkat kemandirian yang kurang atau rendahnya partisipasi dengan lingkungan sekitar. Usia prasekolah dari segi personal, anak seharusnya mampu melakukan aktivitas sederhana secara mandiri, dari aspek sosial, ciri khasnya adalah mulai meluasnya lingkungan pergaulan anak.

Orangtua memiliki periode istimewa dalam menerapkan pola asuh yang tepat bagi anak yakni ketika anak memasuki usia prasekolah. Usia prasekolah (4-6 tahun) menjadi masa kemasan (golden period) bagi anak, dimana pada usia ini selsel otak anak berkembang sangat pesat sehingga segala informasi yang diperoleh dapat direkam secara sempurna. Periode ini perlu dimanfaatkan oleh orang tua untuk meningkatkan kemampuan potensi anak dan mengoptimalkan perkembangan anak setinggi-tingginya. Penerapan pola asuh yang tepat pada masa ini, ditambah dengan stiumulus yang sesuai akan membantu anak menyelesaikan tugas-tugas perkembangan serta menjadi pondasi awal dalam pembentukan karakter anak. Indikator kesesuaian tahap perkembangan personal-sosial anak adalah tingkat kemandirian dan sosialisasi (Soetjiningsih dan Gde Ranuh, 2013).

Anak dapat mengalami keterlambatan perkembangan pada satu ranah perkembangan, atau dapat pula lebih dari satu ranah perkembangan. Dampak dari kegagalan atau keterlambatan perkembangan personal sosial adalah terjadinya frustasi pada anak karena anak tidak mampu bersosialisasi.

Tujuan dari penelitian ini adalah untuk mengetahui hubungan antara pola asuh orangtua dengan perkembangan personal sosial anak usia prasekolah. 


\section{METODE PENELITIAN}

Penelitian ini dilakukan pada tanggal 25 April 2018 - 25 Mei 2018 di TK Thomas Aquino Tuka, Dalung, Kuta Utara. Populasi penelitian adalah seluruh anak usia prasekolah (4-6 tahun) di TK Thomas Aquino berjumlah 197 siswa. Teknik sampling yang digunakan ialah Non Probability Sampling dengan teknik Purposive Sampling. Jumlah sampel yang sesuai dengan kriteria inklusi sebanyak 146 orang. Metode pengambilan data pengukuran pola asuh orangtua pada anak usia prasekolah (4-6 tahun) menggunakan Parenting Style Questionnaire (PSQ), sedangkan observasi dan pengukuran perkembangan personal sosial pada anak usia prasekolah (4-6 tahun) menggunakan Denver II. Uji yang dilakukan adalah uji Koefisien Kontingensi untuk mencari kekuatan hubungan antara kedua variabel dengan kepercayaan $95 \%, \alpha=5 \%(0,05)$.

\section{HASIL}

\section{HASIL DAN DISKUSI}

Peneliti memilih TK Thomas Aquino sebagai tempat penelitian karena memiliki populasi anak usia prasekolah (4-6 tahun) tinggi (197 anak), serta didukung oleh kepala sekolah, staf pengajar, karyawan, orangtua siswa serta siswa yang terbuka dan kooperatif dengan peneliti yang melakukan penelitian.

Tabel 1.

Frekuensi Pola Asuh Orangtua

\begin{tabular}{lccc}
\hline \multicolumn{2}{c}{ Pola Asuh } & Frekuensi (n) & Persentase (\%) \\
\hline Demokratis & & 137 & 93,8 \\
\hline Otoriter & 7 & 4,8 \\
\hline $\begin{array}{l}\text { Kombinasi } \\
\text { Otoriter) }\end{array}$ & (Demokratis- & 2 & 1,4 \\
\hline Total & & 146 & 100 \\
\hline
\end{tabular}

Berdasarkan tabel 1. dapat diketahui bahwa sebagian besar orangtua menerapkan pola asuh demokratis yaitu sebanyak 137 responden $(93,8 \%)$.

Tabel 2.

Frekuensi Perkembangan Personal Sosial Anak

\begin{tabular}{|c|c|c|c|}
\hline $\begin{array}{l}\text { Perkembangan } \\
\text { Sosial }\end{array}$ & Personal & Frekuensi (n) & Persentase $(\%)$ \\
\hline Normal & & 69 & 47,3 \\
\hline Suspect & & 77 & 52,7 \\
\hline Total & & 146 & 100 \\
\hline
\end{tabular}

Berdasarkan tabel 2. didapatkan data bahwa sebagian besar anak mengalami perkembangan personal sosial kategori suspect yaitu 77 anak $(52,7 \%)$. 
Tabel 3.

Hubungan Pola Asuh Orangtua dengan Perkembangan Personal Sosial Anak

\begin{tabular}{lccc}
\hline Keterangan & Normal & Suspect & Jumlah \\
\hline Demokratis & 69 & 68 & 137 \\
\hline Otoriter & - & 7 & 7 \\
\hline $\begin{array}{l}\text { Kombinasi } \\
\text { (Demokratis-Otoriter) }\end{array}$ & - & 2 & 2 \\
\hline Jumlah & 69 & 77 & 146 \\
\hline
\end{tabular}

Berdasarkan tabel 3. dapat diketahui bahwa jumlah orangtua yang menerapkan pola asuh demokratis adalah 137 orang, dengan perkembangan personal sosial anak yang normal sebanyak 69 anak (50,36\%) dan sisanya sebanyak $68(49,64 \%)$ termasuk kategori suspect. Orangtua yang menerapkan pola asuh otoriter berjumlah 7 orang, dengan hasil $100 \%$ anak mengalami perkembangan personal sosial kategori suspect, sedangkan orangtua yang menerapkan pola asuh kombinasi (demokratis-otoriter) sebanyak 2 orang, hasilnya anak mengalami perkembangan personal sosial kategori suspect sebesar $100 \%$.

Tabel 4.

Hasil Uji Korelasi dan Koefisien Kontingensi Pola Asuh Orangtua dengan Perkembangan Personal Sosial Anak

\begin{tabular}{|c|c|c|c|}
\hline & $p$ value & $r$ & $\begin{array}{l}\text { Approximate } \\
\text { Significance }\end{array}$ \\
\hline $\begin{array}{l}\text { Pearson } \\
\text { Square }\end{array}$ & Chi- & & \\
\hline $\begin{array}{l}\text { Contingency } \\
\text { Coefficient }\end{array}$ & & .236 & .014 \\
\hline
\end{tabular}

Hasil uji korelasi dengan chi-square pada tabel 4.7 didapatkan p value 0,014, dengan batas kemaknaan (alfa) sebesar 5\%, maka p value 0,014<0,05 artinya terdapat hubungan yang signifikan antara pola asuh orangtua dengan perkembangan personal sosial anak. hasil uji koefisien kontingensi, dapat kita lihat contingency coefficientnya $(\mathrm{r})$ adalah 0,236 dengan nilai $\mathrm{p}$ value 0,014 , nilai (r) yang diperoleh dari uji korelasi tersebut termasuk kategori sedang.

\section{PEMBAHASAN}

Pola asuh demokratis, otoriter, permisif maupun kombinasi memiliki kelebihan dan kelemahannya masing-masing. Pola asuh demokratis yang menjadi pilihan 93,8\% orangtua, menurut teori yang dikemukakan oleh Septiari (2012) dikatakan memiliki dampak yang baik untuk perkembangan anak, yaitu anak akan mandiri, mempunyai kontrol diri, percaya diri, dapat berinteraksi dengan teman sebayanya dengan baik, mampu menghadapi stres, mempunyai minat terhadap halhal baru, kooperatif dengan orang dewasa, patuh dan berorientasi pada prestasi.

Pola asuh yang tepat menjadi salah satu kebutuhan primer anak karena menentukan karakter anak kelak. Orangtua (responden) dalam penelitian ini sebagian besar menerapkan pola asuh demokratis karena pola asuh ini dianggap memiliki lebih banyak nilai positif dibanding dengan pola asuh otoriter maupun permisif. Orangtua memberikan kebebasan dalam batasan yang sesuai terhadap 
anak-anak mereka, memberikan kesempatan anak mengeksplorasi diri serta menemukan sendiri kesalahannya.

Hasil pengukuran perkembangan personal sosial anak dengan metode laporan dari orangtua serta observasi anak secara langsung menggunakan Denver II didapatkan data bahwa sebanyak 69 anak (47,3\%) mengalami perkembangan personal sosial yang normal, sedangkan 77 lainnya (52,7\%) termasuk dalam kategori suspect (terdapat satu atau lebih tugas perkembangan dengan kategori delayed/ keterlambatan).

Hasil penelitian ini menunjukkan anak mengalami perkembangan normal artinya anak tersebut mampu melakukan tugas-tugas perkembangan sesuai umur. Hal ini terlihat dari anak yang bereaksi tenang saat pemeriksa mencoba berkomunikasi dengannya serta informasi dari hasil wawancara terhadap orangtua bahwa adanya perilaku mandiri di rumah. Hasil wawancara dengan orangtua terhadap anak yang mengalami keterlambatan perkembangan personal sosial kategori suspect, didapatkan hasil bahwa orangtua mempunyai sikap yang berlebihan kepada anaknya sehingga menimbulkan ketidakmandirian pada anak, seperti anak tidak dibiarkan untuk berpakaian sendiri, orangtua terbiasa menyiapkan alat makan dan makanan untuk anak karena takut makanannya tumpah, bahkan ada anak yang harus disuapi oleh orangtuanya.

Orangtua termasuk faktor lingkungan yang memengaruhi perkembangan anak, yaitu lingkungan keluarga karena di sinilah orangtua melakukan interaksi pertama kali dengan anak untuk mengembangkan kemampuan anak sesuai dengan usia perkembangannya. Stimulasi harus diberikan secara rutin dan berkesinambungan dengan kasih sayang, sehingga perkembangan anak akan berjalan optimal. Kurangnya stimulasi dari orangtua dapat menyebabkan keterlambatan perkembangan anak dan membuat anak mengalami perkembangan personal sosial dengan kategori suspect.

Hasil uji korelasi chi-square didapatkan p value 0,014, dengan batas kemaknaan (alfa) sebesar 5\%, maka p value $<0,05$. Penelitian ini menunjukkan bahwa terdapat perbedaan perkembangan personal sosial anak pada orangtua yang menerapkan pola asuh demokratis, otoriter atau kombinasi (demokratis-otoriter), dapat juga diartikan bahwa pola asuh yang diterapkan orangtua dapat berpengaruh besar terhadap perkembangan anak khususnya perkembangan personal sosial.

Hasil uji koefisien kontingensi, atau contingency coefficientnya $(\mathrm{r})$ adalah 0,236 dengan $\mathrm{p}$ value 0,014 . Kriteria hubungan antar variabel adalah bahwa semakin mendekati nilai 1 maka hubungan yang terjadi semakin erat dan jika mendekati nilai 0 maka hubungan semakin lemah. Nilai (r) yang diperoleh dari uji korelasi tersebut termasuk kategori korelasi sedang. Presentase hubungan termasuk kategori sedang, artinya pola asuh berkontribusi $23,6 \%$ terhadap perkembangan personal sosial anak, sisanya atau sebanyak $76,4 \%$ dipengaruhi oleh faktor lain.

\section{Simpulan}

\section{SIMPULAN DAN SARAN}

Pola asuh dominan yang diterapkan oleh orangtua adalah pola asuh demokratis sebanyak 137 responden atau 93,8\%. Perkembangan personal sosial anak usia prasekolah (4-6 tahun) sebagian besar termasuk kategori suspect yaitu sebanyak 77 anak atau 52,7\%. Ada hubungan antara pola asuh orangtua dengan perkembangan personal sosial anak usia prasekolah (4-6 tahun), hasil uji chi square 
didapatkan hasil p value 0,014 dengan koefisien kontingensi (r) adalah 0,236 (korelasi sedang)

\section{Saran}

Tenaga kesehatan (perawat) diharapkan mampu berperan aktif melaksanakan tindakan promotif dan preventif berupa penyuluhan kesehatan atau seminar dengan sasaran orangtua untuk meningatkan pemahaman orangtua mengenai pentingnya pemilihan pola asuh serta perkembangan anak, guna menurunkan angka perkembangan personal sosial anak dengan kategori suspect, serta mampu mengoptimalisasi perkembangan personal sosial anak sehingga anak masuk dalam kategori perkembangan normal.

\section{DAFTAR PUSTAKA}

Anisah, 2011. Pola Asuh Orangtua dan Implikasinya terhadap Pembentukan Karakter Anak. Jurnal Pendidikan Universitas Garut, pp. 70-84.

Asmaliyah, 2009. Hubungan Antara Persepsi Remaja Awal terhadap Pola Asuh Orangtua Otoriter dengan Motivasi Berprestasi. Malang: UIN Maulana Malik Ibrahim Press.

Drey, 2011. Ketika Anak Sulit Diatur : Panduan Orangtua Mengubah Masalah Perilaku Anak. Bandung: PT Mizan Pustaka.

Fitria, N., 2015. Pola Asuh Orangtua dalam Mendidik Anak Usia Prasekolah Ditinjau dari Aspek Budaya Lampung. Jurnal Fokus Konseling Volume 2 No. 2, pp. 99-115.

Hidayat, A. H. 2009. Metode Penelitian Keperawatan dan Teknik Analisis Data. Jakarta: Salemba Medika. . 2007. Metode Penelitian Keperawatan dan Teknik Analisa Data. Jakarta: Salemba Medika. . 2003. Riset Keperawatan dan Teknik Penulisan Ilmiah. Jakarta: Salemba Medika.

Hurlock, E., 2007. Psikologi Perkembangan Suatu Pendekatan Sepanjang Rentang Kehidupan. Jakarta: PT Erlangga.

IPANI, 2017. Ikatan Perawat Anak Indonesia. [Online] Available at: http://www.ipani.or.id/seminar-ipani-propinsi-bali-dalam rangka-menyambut-hari-anak-nasional-2017/

KemenkesRI, 2014. Kondisi Pencapaian Program Kesehatan Anak Indonesia, Jakarta: Pusat Data dan Informasi Kementrian Kesehatan Indonesia.

Lasiyati Yuswo Yani, Ervin Wurandiati, 2012. Hubungan Pola Asuh Orangtua dengan Perkembangan Personal Sosial, Motorik dan Bahasa Anak Prasekolah. Jurnal Stikes Bina Sehat, pp. 19-26.

Lestari, S., 2012. Psikologi Keluarga. Jakarta: Kencana.

Mahmud, 2011. Metodologi Penelitian Pendidikan. Bandung: Pustaka Setia.

Mudiastuti, L. P. A., 2016. Hubungan Pola Asuh Orangtua dengan Kemampuan Sosialisasi Anak Prasekolah.

Mulyani, 2014. Penggunaan Model Pembelajaran dengan Pendekatan Konstruktivisme untuk Meningkatkan Kemampuan Berfikir Kritis dan Kreatif Matematis. Jakarta: Jurusan Farmasi Universitas Terbuka.

Notoatmodjo, S., 2010. Metodologi Penelitian Kesehatan. Jakarta: Rineka Cipta. 
Nursalam, 2008. Konsep dan Penerapan Metodologi Penelitian Ilmu Keperawatan. Jakarta: Salemba Medika. , 2011. Manajemen Keperawatan Edisi 3. Jakarta: Salemba Medika. , 2013. Konsep dan Penerapan Metodologi Penelitian Ilmu Keperawatan. Jakarta: Salemba Medika. , 2016. Metodologi Penelitian Ilmu Keperawatan : Pendekatan Praktis. Jakarta: Salemba Medika.

Onder, A. dan Gulay,H., 2009. Reliability And Validity of Parenting Styles \& Dimensions Questionnaire. Procedia Social and Behavioral Sciences I. Elsevier., 1, pp.508-514.

Pratiwi, A., 2013. Hubungan antara Pola Asuh Orangtua dengan Perkembangan Mental Anak pada Proses Tumbuh Kembang di SD Bentakan 1 Sukoharjo. Kosala, Volume 1, pp. 24-29.

Putri, D. A. W. M., 2009. Pola Asuh Antargenerasi pada Masyarakat Bali Aga (Bali Asli) : Kajian Psikologi Indigenous pada Masyarakat Desa Panglipuran Bangli, Bali. ETD.

Respati Winanti Siwi, Anes Yulianto, Noryta Widiana, 2006. Perbedaan Konsep Diri antara Remaja Akhir yang Mempersepsi Pola Asuh Orangtua Authotarian, Permissive dan Authoritative. Jurnal Psikologi Volume 4, pp. 119-138.

Robinson, Mandleco, Olsen, Hart, 1995. Authoritative, Authoritarian, and Permissive Parenting Practices : Development of a new measure. Psychologicl Reports, pp. 77, 819-830.

Schohib, 2010. Pola Asuh Orangtua dalam Membantu Anak Mengembangkan DIsiplin Diri. Jakarta: Rineka Cipta.

Septiari, B. B., 2012. Mencetak Balita Cerdas dan Pola Asuh Orangtua. Yogyakarta: Nuha Medika.

Setiani, W. A., 2017. Hubungan Pola Asuh Orangtua dengan Perkembangan Personal Sosial di TK ABA Godegan Bantul. Stikes Jenderal Ahmad Yani.

Setyabudi, 2003. Anak Unggul Berotak Prima. Jakarta: Gramedia.

Soetjiningsih, Gde Ranuh, 2013. Tumbuh Kembang Anak Edisi 2. Jakarta: EGC.

Soetjiningsih, C. H., 2012. Perkembangan Anak. Jakarta: Prenada Media.

Sugiyono, 2013. Metode Penelitian Pendidikan Pendekatan Kuantitatif, KUalitatif dan $R \& D$. Bandung: Alfabeta. . 2008. Metode Penelitian Pendidikan (Pendekatan Kuantitatif, Kualitatif dan $R \& D)$. Bandung: Alfabeta.

Suharsono, Fitriyani, Upoyo, 2009. Hubungan Pola Asuh Orangtua terhadap Kemampuan Sosialisasi pada Anak Prasekolah. Jurnal Keperawatan Soedirman, pp. 112-118.

Suyanto, 2011. Metodologi dan Analisis Penelitian. Yogyakarta: Nuha Medika.

Triani Yuliastanti, Novita Nurhidayati , 2013. Pola Asuh Perkembangan Personal Sosial Anak Toddler. pp. 1-7.

Wasis, 2008. Pedoman Riset Praktis untuk Profesi Perawat. Jakarta: EGC.

Yusuf, S., 2012. Psikologi Perkembangan Anak dan Remaja. Bandung: PT Remaja Rosdakarya . 